\title{
Association between Physiological Equivalent Temperature (PET) with adverse pregnancy outcomes in Ahvaz, southwest of Iran
}

\author{
Maryam Dastoorpoor ${ }^{1}$, Narges Khanjani ${ }^{2}$ and Narges Khodadadi ${ }^{*^{*}}$
}

\begin{abstract}
Background: There are few epidemiological studies on the relation between temperature changes and adverse pregnancy outcomes. The purpose of this study was to determine the relation between Physiological Equivalent Temperature (PET) with adverse pregnancy outcomes including stillbirth, low birth weight (LBW), preterm labor (PTL), spontaneous abortion (SA), preeclampsia and hypertension in Ahvaz, Iran.

Methods: Distributed Lag Non-linear Models (DLNM) combined with quasi-Poisson regression were used to investigate the effect of PET on adverse pregnancy outcomes. In this study the effect of time trend, air pollutants $\left(\mathrm{NO}_{2}, \mathrm{SO}_{2}\right.$ and $\left.\mathrm{PM}_{10}\right)$, and weekdays were adjusted.

Results: High PET $\left(45.4 \mathrm{C}^{\circ}, \mathrm{lag}=0\right)$ caused a significant increase in risk of stillbirth. Also, high levels of PET (45.4, $43.6,42.5 C^{\circ}$, lag $\left.=0-6\right)$ and low levels of PET $\left(9.9,16.9 C^{\circ}\right.$, lags $\left.=0,0-13,0-21\right)$ significantly increased the risk of LBW. But, low levels of PET $\left(6.4,9.9,16.9 C^{\circ}\right.$, lags $\left.=0-6,0-13\right)$ reduced the risk of gestational hypertension.

Conclusion: The results of this study showed that hot and cold thermal stress may be associated with increased risk of stillbirth, and LBW in Ahvaz.
\end{abstract}

Keywords: Temperature, Thermal index, Physiological Equivalent Temperature, Pregnancy Outcome

\section{Background}

Weather conditions can affect human health and activities [1]. Heat stress is a major cause of climate-related deaths. As temperatures continue to increase due to climate change, heat stress is expected to worsen [2]; and negative outcomes might increase as a result of human exposure to extreme weather conditions. Researchers think one of the most important weather-related causes of mortality in the developed and developing world, is

\footnotetext{
* Correspondence: narges.khodadad@yahoo.com

'Department of Epidemiology and Biostatistics, Menopause Andropause Research Center, Ahvaz Jundishapur University of Medical Sciences, Ahvaz, Iran

Full list of author information is available at the end of the article
}

extreme heat [3]. Previous studies conducted in Iran have reported that the risk of mortality due to extreme heat was higher than other unfavorable temperatures [4]. Studies have reported that heat-related deaths were more prone to occur on days with a peak temperature above $38{ }^{\circ} \mathrm{C}$, and there was an exponential relation between the incidence of these deaths and the number of hot days per year [5].

Recently, several studies have focused on the possible effects of ambient temperature on pregnancy outcomes. For example, Yu et al. (2018) reported mixed effects of temperature on preterm birth, in the tropical island of Puerto Rico. But, other studies have reported a positive relation between exposure to heat waves in all months

(c) The Author(s). 2021 Open Access This article is licensed under a Creative Commons Attribution 4.0 International License, which permits use, sharing, adaptation, distribution and reproduction in any medium or format, as long as you give appropriate credit to the original author(s) and the source, provide a link to the Creative Commons licence, and indicate if changes were made. The images or other third party material in this article are included in the article's Creative Commons licence, unless indicated otherwise in a credit line to the material. If material is not included in the article's Creative Commons licence and your intended use is not permitted by statutory regulation or exceeds the permitted use, you will need to obtain permission directly from the copyright holder. To view a copy of this licence, visit http://creativecommons.org/licenses/by/4.0/. The Creative Commons Public Domain Dedication waiver (http://creativecommons.org/publicdomain/zero/1.0/) applies to the data made available in this article, unless otherwise stated in a credit line to the data. 
of pregnancy and preterm birth, while exposure during early pregnancy was more likely to increase the risk of stillbirth, compared with exposure in the last months of pregnancy [6]. Several studies have reported associations between stillbirth and higher temperatures during the week before delivery [7-10]. Other studies have shown the effect of high temperatures on preterm birth [11], gestational diabetes mellitus [12] and birth weight [13]. A 2017 analysis in the US estimated that exposures to extreme ambient temperature including cold exposures during the second and third trimesters, and hot exposures during the third trimester of pregnancy, compared to average temperatures may increase the risk of low birth weight [8]. Another study showed that singleton primiparous women who conceived in summer and had a longer exposure to higher ambient temperature were at a greater risk of preeclampsia [14]. Likewise, other researchers found that rise in temperature 30 days after conception and in the first trimester of pregnancy, increased the risk of severe pre-eclampsia especially when conception had happened in summer [15]. And others claimed that cumulative and acute exposures to extremely low or high temperatures, both may induce emotional stress during pregnancy [16], and increase the risk of hypertension in pregnancy during cold months [17-19].

Human thermal discomfort can be measured by various indices [1]. Since 1950, human thermal comfort in indoor and outdoor environments has been discussed in numerous reports, leading to various numerical and diagram-based indices [20]. Currently, there are more than 60 heat stress indices, which have their own advantages and disadvantages [21]. This indicates that the assessment of heat stress in terms of physiological and psychological strain in humans is complex. The many indices that have been suggested can be categorized into one of these three groups: "rational indices", "empirical indices", or "direct indices". The first and second groups are sophisticated indices, which integrate environmental and physiological variables. They are difficult to calculate and are not feasible for daily use. The last group consists of simple indicators based on the measurement of underlying environmental variables [22].

One of the most popular indices used to measure heat stress in outdoor spaces is physiological equivalent temperature (PET), deviated from the Munich Energy Balance for Individuals (MEMI) [23]. PET is defined as a complete budget model for the heat of the human body (Höppe1984, 1999), and provides the equivalent temperature of an isothermal reference environment with a water vapor pressure of $12 \mathrm{hPa}\left(50 \%\right.$ at $\left.20{ }^{\circ} \mathrm{C}\right)$ and light wind $(0.1 \mathrm{~m} / \mathrm{s})$, at which the heat balance of a reference person is maintained with core and skin temperature equal to those under the conditions being assessed. For the reference person, an optimal indoor environment is chosen and a work metabolism of $80 \mathrm{~W}$ will be added to the basic metabolism and clothing insulation should be fixed at 0.9 Clo. The effect of humidity on PET is limited to the latent heat fluxes via respiration and through diffusion through the skin [24]. The assessment of PET has its roots in Fanger's (1970) PMV, calculated for different air temperatures in the reference environment, using the settings for the PET reference person [25].

According to numerous studies, the dangers of climate change on human health are undeniable. Although pregnant women are a sensitive group, the extent of these changes during pregnancy is still unknown. The present study is the first study about the effects of temperature on adverse pregnancy outcomes in Iran and the Middle East.

The aim of the present paper is to study the relation between PET and stillbirth, low birth weight (LBW), preterm labor (PTL), spontaneous abortion (SA), preeclampsia and gestational hypertension in a 10 year (2008-2018) time frame in Ahvaz, Iran.

\section{Methods \\ Study site}

Ahvaz is the seventh most populous city of Iran. Ahvaz is the capital city of Khuzestan province in the south-west of Iran. Ahvaz is located at $31^{\circ} 20^{\prime} \mathrm{N}$ and $48^{\circ} 40^{\prime} \mathrm{E}$. It's area is $185 \mathrm{~km}^{2}$ and is $12 \mathrm{~m}$ above sea level. In the 2016 census, the population of this city was approximately $1,300,000$ [26]. Ahvaz has a desert climate with hot long summers and short mild winters. Ahvaz is often the hottest city in the world during summer, with high consistent temperatures between 45 and $50{ }^{\circ} \mathrm{C}$. The annual average temperature in this city is $25.4{ }^{\circ} \mathrm{C}$. Ahvaz recorded the temperature of $54{ }^{\circ} \mathrm{C}$ which was the highest temperature recorded in the world on June 29, 2017 [27].

\section{Data}

Data about adverse pregnancy outcomes including stillbirth, LBW, PTL, SA, preeclampsia and hypertension (diagnosed in the clinic and recorded with date in the patients files) were collected from the population of pregnant women that visited two big referral hospitals in Ahvaz, named the Imam Khomeini, and Razi Hospital, from 2008 to 2018 (10 years). The diagnoses were based on ICD-10 and included the following codes; stillbirth (Z37.1), low birth weight (P07.0), preterm labor (O60), spontaneous abortion (O03), pre-eclampsia (O14), and gestational hypertension (O13).

The data was inquired on a daily basis, from the beginning of April 2008 until March 2018. The total number of pregnant women who visited the Obstetrics and Gynecology department during this 10 -year period was 150,766 . 
Meteorological parameters including average daily temperature, maximum daily temperature, minimum daily temperature, average wind speed, relative humidity, and cloudiness were obtained from the Khuzestan Meteorological Department. Ahvaz city has one synoptic meteorology station, in which different atmospheric factors such as temperature, type of clouds, rainfall and cloudiness is determined according to specific instructions, and recorded at certain hours, daily. This station is $22.5 \mathrm{~m}$ above sea level, at $48^{\circ} 40^{\prime} \mathrm{E}$ longitude and $31^{\circ} 20^{\prime} \mathrm{N}$ latitude, inside Ahvaz.

Data about ambient air pollutants were inquired from the Ahvaz Environmental Protection Organization and included $\mathrm{SO}_{2}, \mathrm{PM}_{10}, \mathrm{NO}_{2}$. There are four air pollution monitoring stations in Ahvaz city and in this study the average of the four stations were used. Missing air pollutants data were estimated using the EM (ExpectationMaximization) method [28].

The Expectation Maximum method uses the available data to create regression models that estimate missing data. In this method, regression parameters are reestimated several times and updated regularly using new sets. That is, initially the available data is used to estimate the parameters of the model. Then the available data and the estimated data, are used to re-estimate the missing data. This process is repeated until the difference between two consecutive regression coefficients becomes less than $10^{-6}$ [28]. In this study, there was no missing meteorological data, but there was less than $10 \%$ missing in air pollution data, that was estimated using EM.

\section{PET index}

The data required to calculate the PET index are 1- Meteorological parameters including air temperature in degrees Celsius $\left(C^{\circ}\right)$, relative humidity in percentage $(\%)$, wind speed in meters per second $(\mathrm{m} / \mathrm{s})$, cloudiness in Oktas (octants), vapour pressure of water in hectopascal $(\mathrm{hPa})$, radiation temperature in degrees Celsius $\left(\mathrm{C}^{\circ}\right)$, global radiation $(G)$ in Watts per square meter $\left(W / \mathrm{m}^{2}\right)$, 2- Physiological data including height, weight, age, gender, amount of clothing in clo (clo), amount of physical activity in Watts (W), 3- Geographic data including latitude, longitude and altitude of the meteorological measurement stations. Physiological parameters are different in different people. In order to calculate the PET index, the physiological parameters for all people are considered a standard amount; gender is assumed female, height is set at 175 centimeter, weight at $75 \mathrm{~kg}$, age at 35 years, clothing $=0.9 \mathrm{Clo}$ and physical activity level equal to $80 \mathrm{~W}$ [29].

Analysis of PET index was performed using the Rayman software. The RayMan software is a simulation tool used in human-biometeorology. Details about this software can be found elsewhere [30].

The classification of PET index in Iran is presented in Table $1(16,29)$. The thermal comfort point for PET is from 17.8 to $27^{\circ} \mathrm{C}$, at this point there is no thermal stress imposed on humans.

In order to investigate the effect of PET index on study outcomes, two separate analysis were performed. First, the association between low values (comparison of 1,5 and 25th percentiles relative to no thermal stress) and high values (comparison of 90, 95 and 99th percentiles relative to no thermal stress) of PET index with the risk of adverse pregnancy outcomes, in zero cumulative models, 0-2, 0-6, 0-13 and 0-21 days lag was determined. The median of PET, defined as the no thermal stress class, was respectively $22.5^{\circ} \mathrm{C}$ and was used as the basis for comparison with other high and low thermal stress values. Zero cumulative models used in this study was models estimating the effect of exposure from day 0 until a particular day. For example, the 0-2 model, means the effect observed from day 0 (same day, lag $=0$ ) until day 2 (lag = 2 days).

Second, the association between cold thermal stress (comparison of 1 th percentile relative to 25 th percentile) and hot thermal stress (comparison of 75 th percentile relative to 99th percentile) of PET index with risk of adverse pregnancy outcomes, in zero cumulative models, $0-2,0-6,0-13$ and $0-21$ days lag was calculated according to methods used in previous references [31-33].

\section{Statistical Analysis}

In order to investigate the effect of PET on adverse pregnancy outcomes, Distributed Lag Non-linear Models (DLNM) combined with quasi-Poisson regression models were used. The DLNM model, is based on cross-basis functions, and is used for simultaneous estimation of the nonlinear relation between exposure and outcome in different time lags [34].

Table 1 Thermal sensation and different groups of PET

\begin{tabular}{lll}
\hline PET $\left({ }^{\circ} \mathbf{C}\right)$ in Iran $^{\mathbf{a}}$ & Thermal sensation & Physiological stress level \\
\hline$<-10.7$ & Very cold & Extreme cold stress \\
-10.7 to -0.7 & Cold & Strong cold stress \\
-0.7 to 8.8 & Cool & Moderate cold stress \\
8.8 to 17.8 & Slightly cool & Slight cold stress \\
17.8 to 27.0 & Comfortable & No thermal stress \\
27.0 to 35.1 & Slightly warm & Slight heat stress \\
35.1 to 43.0 & Warm & Moderate heat stress \\
43.0 to 50.8 & Hot & Strong heat stress \\
$>50.8$ & Very hot & Extreme heat stress
\end{tabular}

aable taken from Sharafkhani et al. [31] 
In this study, a natural cubic-spline DLNM was used to determine the nonlinear relation of PET index and also the cumulative lag effects up to a maximum of 21 days, similar to previous studies [35, 36], with adverse pregnancy outcomes.

Spline knots were set at equally spaced values on the log scale of lags. The long term, seasonal trend of adverse pregnancy outcomes was adjusted by a natural cubic spline function of time with 7 degrees of freedom per years of study (10 years). $\mathrm{PM}_{10}, \mathrm{SO}_{2}$ and $\mathrm{NO}_{2}$ were controlled using the stratified distributed lag model for up to 7 days lag with 3 degrees of freedom [31]. Also, the holidays and weekdays variable was adjusted as a categorical variable in the final model [31]. Akaike Information Criterion (AIC) was used to select the most appropriate model and degrees of freedom (knots) for thermal index and lags [34]. Five degrees of freedom were considered as the best model for thermal index and time lags. The risk ratio and $95 \%$ confidence interval were estimated for the associations. The analysis was performed utilizing $\mathrm{R}$ software version 3.5.3 through the dlnm package. P-values less than 0.05 were considered significant.

\section{Results}

The descriptive statistics of the PET index, stillbirth, LBW, PTL, SA, preeclampsia and gestational hypertension are presented in Table 2. During the 10-years study period, the highest and lowest adverse pregnancy outcomes were respectively preterm labors (5776 cases) and stillbirths (1965 cases). The mean \pm SD of PET was $27.6 \pm 11.6$ (Table 2).

Table 2 Descriptive statistics of adverse pregnancy outcomes, air pollutants, PET in Ahvaz city, 2008-2018

\begin{tabular}{llclll}
\hline Variable (Mean per day) & $\mathbf{N}$ & Mean \pm SD & Median & Min & Max \\
\hline Stillbirth & 1965 & $0.5 \pm 0.8$ & 0 & 0 & 5 \\
$\mathrm{LBW}^{\mathrm{a}}$ & 863 & $0.2 \pm 0.6$ & 0 & 0 & 5 \\
$\mathrm{PTL}^{\mathrm{b}}$ & 5776 & $1.6 \pm 1.9$ & 1 & 0 & 12 \\
$\mathrm{SA}^{\mathrm{c}}$ & 5063 & $1.4 \pm 1.4$ & 1 & 0 & 8 \\
Pre-Eclampsia & 4357 & $1.2 \pm 1.2$ & 1 & 0 & 8 \\
$\mathrm{Gestational}$ hypertension & 4030 & $1.1 \pm 1.2$ & 1 & 0 & 13 \\
$\mathrm{NO}_{2}{ }^{\mathrm{d}}\left(\mu \mathrm{g} / \mathrm{m}^{3}\right)$ & --- & $46.4 \pm 43.1$ & 35.6 & 1.5 & 443.8 \\
$\mathrm{SO}_{2}{ }^{\mathrm{e}}\left(\mu \mathrm{g} / \mathrm{m}^{3}\right)$ & --- & $48.8 \pm 57.0$ & 35.9 & 0 & 907.4 \\
$\mathrm{PM}_{10}{ }^{\mathrm{f}}\left(\mu \mathrm{g} / \mathrm{m}^{3}\right)$ & --- & $216.9 \pm 278.3$ & 149.2 & 1.8 & 4324.2 \\
$\mathrm{PET}^{\mathrm{g}}$ & --- & $27.6 \pm 11.6$ & 27.9 & 0.8 & 47.3
\end{tabular}

aLow birth weight

${ }^{b}$ Preterm labor

'Spontaneous abortion

dNitrogen dioxide

eSulfur dioxide

fParticulate matter less than 10 microns

${ }^{\text {gPhysiological equivalent temperature }}$

\section{PET index and adverse pregnancy outcomes}

The association between the PET index and adverse pregnancy outcomes in 1st $\left(6.4^{\circ} \mathrm{C}\right)$, 5th $\left(9.9^{\circ} \mathrm{C}\right)$, 25th $\left(16.9^{\circ} \mathrm{C}\right)$, 90th $\left(42.5^{\circ} \mathrm{C}\right)$, 95th $\left(43.6^{\circ} \mathrm{C}\right)$ and 99th $\left(45.4^{\circ} \mathrm{C}\right)$ percentiles relative to $\mathrm{PET}=22.5{ }^{\circ} \mathrm{C}$ is presented in Table 3.

The results in Table 3 show that high PET values in the 99th percentile compared to no thermal stress, at lag 0 increased the risk of stillbirth significantly. Also in relation to the LBW outcome, both high values of PET in 90th, 95th and 99th percentiles, in the cumulative lag of $0-6$ and low values of PET in the 5th and 25th percentiles in 0, 0-13 and 0-21 day lags, compared to no thermal stress, significantly increased the risk of LBW (Table 3). Regarding gestational hypertension, the results showed that low levels of PET in the 1st, 5th, and 25th percentiles compared to no thermal stress, at lags $0-6$ and $0-13$ reduced the risk of gestational hypertension (Table 3). Significant changes were not observed in the risk of other pregnancy outcomes including PTL, SA and pre-eclampsia, with PET values in any lag (Table 3). The results of intensified thermal stress analysis showed that hot thermal stress (comparing the 99th percentile to 75th percentile) significantly increased the risk of stillbirth in lags 0 and $0-13$ and LBW in lag 0-13 (Table 4; Fig. 1).

\section{Discussion}

Pregnant mothers and growing embryos are among the populations likely to be susceptible to climate change. Climate change may have a significant impact on the health and survival of future human generations [37].

The purpose of the present study was to determine the relation between PET index with adverse pregnancy outcomes including stillbirth, low birth weight, preterm labor, spontaneous abortion, preeclampsia and gestational hypertension in Ahvaz city.

In the present study, the results showed that high values of PET (the 99th percentile) and hot thermal stress according to the PET index, increased the risk of stillbirth. Similarly, Asamoah et al., studied the association between ambient heat exposure and stillbirths in Ghana; and showed that for every one degree increase in wet-bulb globe temperature (WBGT), the risk of stillbirth or miscarriage increased $12-15 \%$. Although this increase was not statistically significant, but the small range of WBGT changes over the months and years may have hidden the real impact of high temperature levels [38]. Other studies have confirmed the effect of heat stress on stillbirth as well. Rammah et al., (2019), conducted a study to examine associations between increases of apparent temperature and stillbirths during the warm season (May-September), among 708 women, from 6 days before stillbirth, in Harris County, Texas, from 2008 to 2013 . The results showed that a $10{ }^{\circ} \mathrm{F}$ 
Table 3 The cumulative relative risks of adverse pregnancy outcomes in high and low PET ${ }^{a}$ values relative to $\mathrm{PET}=22.5^{\circ} \mathrm{C}$

\begin{tabular}{|c|c|c|c|c|c|c|c|}
\hline \multirow{2}{*}{$\begin{array}{l}\text { Repercussions } \\
\text { Stillbirth }\end{array}$} & \multicolumn{2}{|c|}{$\begin{array}{l}\text { PET } \\
\text { value }\left({ }^{\circ} \mathrm{C}\right)\end{array}$} & \multirow{2}{*}{$\begin{array}{l}\text { Lag } 0 \\
1.980(1.097-3.574)\end{array}$} & \multirow{2}{*}{$\begin{array}{l}\text { Lag } \mathbf{0 - 2} \\
1.602(0.793-3.234)\end{array}$} & \multirow{2}{*}{$\begin{array}{l}\text { Lag } \mathbf{0 - 6} \\
1.282(0.505-3.253)\end{array}$} & \multirow{2}{*}{$\begin{array}{l}\text { Lag } \mathbf{0 - 1 3} \\
1.747(0.457-6.676)\end{array}$} & \multirow{2}{*}{$\begin{array}{l}\text { Lag } \mathbf{0 - 2 1} \\
1.750(0.315-9.707)\end{array}$} \\
\hline & $\mathrm{H}^{\mathrm{b}}$ & 45.4 & & & & & \\
\hline & & 43.6 & $1.667(0.960-2.895)$ & $1.425(0.746-2.722)$ & $1.166(0.501-2.711)$ & $1.396(0.422-4.616)$ & $1.350(0.299-6.093)$ \\
\hline & & 42.5 & $1.515(0.887-2.587)$ & $1.334(0.716-2.485)$ & $1.105(0.496-2.461)$ & $1.228(0.401-3.763)$ & $1.1610 .288-4.69)$ \\
\hline & $L^{c}$ & 16.9 & $0.961(0.810-1.140)$ & $0.956(0.782-1.168)$ & $0.903(0.694-1.174)$ & $0.930(0.638-1.359)$ & $1.116(0.691-1.802)$ \\
\hline & & 9.9 & $1.023(0.734-1.426)$ & $0.888(0.601-1.311)$ & $0.655(0.392-1.093)$ & $0.620(0.298-1.288)$ & $0.770(0.304-1.955)$ \\
\hline & & 6.4 & $0.894(0.606-1.319)$ & $0.752(0.486-1.163)$ & $0.579(0.334-1.004)$ & $0.589(0.270-1.288)$ & $0.747(0.277-2.016)$ \\
\hline \multirow[t]{6}{*}{ LBW } & $\mathrm{H}$ & 45.4 & $0.918(0.349-2.416)$ & $1.280(0.422-3.885)$ & $4.966(1.161-21.241)$ & 7.181 (0.860-59.949) & $2.938(0.192-45.004)$ \\
\hline & & 43.6 & $0.848(0.341-2.111)$ & $1.239(0.443-3.467)$ & $4.180(1.099-15.896)$ & $5.278(0.764-36.458)$ & $2.367(0.203-27.641)$ \\
\hline & & 42.5 & $0.812(0.334-1.973)$ & $1.213(0.45-3.269)$ & $3.758(1.047-13.493)$ & $4.383(0.7-27.463)$ & $2.069(0.204-20.939)$ \\
\hline & $L$ & 16.9 & $1.425(1.100-1.846)$ & 1.299 (0.955-1.768) & $1.277(0.835-1.951)$ & $2.058(1.067-3.972)$ & $2.613(1.084-6.296)$ \\
\hline & & 9.9 & $1.650(1.021-2.666)$ & $1.338(0.754-2.373)$ & $1.254(0.573-2.743)$ & $2.230(0.664-7.496)$ & $2.450(0.478-12.550)$ \\
\hline & & 6.4 & $1.004(0.522-1.932)$ & $0.983(0.476-2.030)$ & $0.775(0.314-1.915)$ & $0.732(0.179-2.993)$ & $0.788(0.131-4.729)$ \\
\hline \multirow[t]{6}{*}{ PTL } & $\mathrm{H}$ & 45.4 & $1.1060(0.755-1.621)$ & $0.968(0.614-1.526)$ & $0.745(0.405-1.368)$ & $0.772(0.313-1.907)$ & $0.962(0.294-3.147)$ \\
\hline & & 43.6 & $1.154(0.805-1.653)$ & $1.030(0.674-1.575)$ & $0.822(0.471-1.434)$ & $0.879(0.392-1.969)$ & $1.068(0.377-3.024)$ \\
\hline & & 42.5 & $1.179(0.831-1.673)$ & 1.065 (0.707-1.606) & $0.868(0.511-1.476)$ & $0.942(0.443-2.006)$ & $1.128(0.431-2.956)$ \\
\hline & $L$ & 16.9 & $0.971(0.866-1.089)$ & $0.892(0.780-1.019)$ & $0.855(0.719-1.017)$ & $0.854(0.667-1.094)$ & $0.801(0.585-1.097)$ \\
\hline & & 9.9 & $0.930(0.752-1.149)$ & $0.773(0.605-0.988)$ & $0.713(0.521-0.974)$ & $0.758(0.488-1.176)$ & $0.695(0.398-1.211)$ \\
\hline & & 6.4 & $0.964(0.761-1.220)$ & $0.892(0.691-1.152)$ & $0.974(0.707-1.340)$ & $1.212(0.762-1.925)$ & 1.219 (0.676-2.198) \\
\hline \multirow[t]{6}{*}{ SA } & $\mathrm{H}$ & 45.4 & $0.903(0.612-1.333)$ & $0.971(0.611-1.541)$ & $0.966(0.522-1.786)$ & $0.852(0.349-2.080)$ & $0.978(0.311-3.079)$ \\
\hline & & 43.6 & $0.867(0.605-1.244)$ & $0.978(0.641-1.491)$ & $1.002(0.576-1.743)$ & $0.855(0.386-1.893)$ & $0.982(0.359-2.688)$ \\
\hline & & 42.5 & 0.849 (0.599-1.204) & $0.982(0.656-1.471)$ & $1.023(0.605-1.728)$ & $0.860(0.409-1.808)$ & $0.986(0.388-2.506)$ \\
\hline & $L$ & 16.9 & $1.032(0.921-1.156)$ & $1.055(0.923-1.205)$ & $1.021(0.855-1.218)$ & $0.971(0.749-1.259)$ & $0.968(0.695-1.350)$ \\
\hline & & 9.9 & $1.088(0.874-1.354)$ & $1.140(0.881-1.476)$ & $1.095(0.778-1.541)$ & $1.089(0.662-1.791)$ & $1.172(0.619-2.218)$ \\
\hline & & 6.4 & $1.022(0.799-1.308)$ & $1.053(0.798-1.389)$ & $1.007(0.707-1.435)$ & $1.015(0.610-1.689)$ & $1.125(0.586-2.160)$ \\
\hline \multirow[t]{6}{*}{ Pre-Eclampsia } & $\mathrm{H}$ & 45.4 & $0.838(0.557-1.262)$ & $0.809(0.496-1.318)$ & $1.033(0.540-1.977)$ & $1.436(0.560-3.682)$ & $1.580(0.471-5.306)$ \\
\hline & & 43.6 & $0.831(0.568-1.215)$ & $0.784(0.501-1.229)$ & $0.979(0.544-1.764)$ & $1.291(0.558-2.983)$ & $1.347(0.465-3.898)$ \\
\hline & & 42.5 & $0.827(0.572-1.196)$ & $0.772(0.502-1.188)$ & $0.951(0.544-1.663)$ & $1.213(0.554-2.655)$ & $1.227(0.46-3.275)$ \\
\hline & $L$ & 16.9 & $1.110(0.985-1.250)$ & $0.997(0.866-1.146)$ & $0.838(0.697-1.007)$ & $0.886(0.682-1.152)$ & $1.018(0.733-1.413)$ \\
\hline & & 9.9 & $1.216(0.964-1.533)$ & $0.990(0.755-1.297)$ & $0.738(0.519-1.049)$ & $0.767(0.466-1.262)$ & $0.807(0.431-1.511)$ \\
\hline & & 6.4 & $1.195(0.923-1.547)$ & $1.034(0.778-1.374)$ & $0.926(0.648-1.322)$ & $1.009(0.605-1.682)$ & $0.906(0.470-1.746)$ \\
\hline \multirow[t]{6}{*}{ Gestational hypertension } & $\mathrm{H}$ & 45.4 & $1.075(0.687-1.682)$ & $0.987(0.580-1.680)$ & $1.151(0.570-2.321)$ & $1.431(0.518-3.952)$ & $1.332(0.363-4.882)$ \\
\hline & & 43.6 & $1.069(0.705-1.620)$ & 1.009 (0.619-1.643) & $1.220(0.646-2.304)$ & $1.529(0.618-3.783)$ & $1.401(0.446-4.401)$ \\
\hline & & 42.5 & $1.067(0.713-1.595)$ & $1.022(0.64-1.633)$ & $1.261(0.69-2.305)$ & 1.585 (0.678-3.704) & $1.440(0.499-4.161)$ \\
\hline & L & 16.9 & $0.975(0.856-1.111)$ & $0.952(0.819-1.107)$ & $0.791(0.649-0.965)$ & $0.693(0.519-0.924)$ & $0.773(0.537-1.114)$ \\
\hline & & 9.9 & $1.042(0.817-1.329)$ & $0.956(0.720-1.270)$ & $0.668(0.458-0.975)$ & $0.553(0.320-0.956)$ & $0.660(0.329-1.325)$ \\
\hline & & 6.4 & $0.950(0.724-1.246)$ & $0.863(0.638-1.168)$ & $0.676(0.459-0.997)$ & $0.625(0.356-1.098)$ & $0.738(0.358-1.521)$ \\
\hline
\end{tabular}

\footnotetext{
a Physiological Equivalent Temperature $\left({ }^{\circ} \mathrm{C}\right)$

${ }^{\mathrm{b}}$ High PET values

c Low PET values
}

increase in apparent temperature in the week before delivery was related to a $45 \%$ increased risk of stillbirth (adjusted OR $=1.45,95 \%$ confidence interval (CI): 1.18, 1.77) [7]. Likewise, another study in California showed for every $10^{\circ} \mathrm{F}$ increase in apparent temperature during the warm season, the risk of stillbirth increased by
$10.4 \%$ after 2-6 days lag, while there was no significant relation between temperature and stillbirth during the cold season [10]. A study conducted by Strand et al., (2011), in Brisbane city, Australia, during 2005-2009, reported that high ambient temperature during the last 4 weeks of pregnancy increased the risk of stillbirth 
Table 4 The cumulative relative risks of adverse pregnancy outcomes in intensified thermal stress of PET

\begin{tabular}{|c|c|c|c|c|c|}
\hline Hot Effect (PET) ${ }^{\mathrm{a}}$ & $\operatorname{Lag} 0$ & Lag 0-2 & Lag 0-6 & $\operatorname{Lag} 0-13$ & Lag 0-21 \\
\hline Stillbirth & $1.638(1.203-2.232)$ & 1.407 (0.969-2.044) & $1.329(0.817-2.162)$ & $1.977(1.004-3.893)$ & $2.247(0.941-5.363)$ \\
\hline LBW & $1.244(0.763-2.027)$ & $1.144(0.648-2.022)$ & $1.856(0.906-3.802)$ & $2.855(1.046-7.790)$ & $2.200(0.595-8.142)$ \\
\hline PTL & $0.904(0.749-1.092)$ & $0.848(0.675-1.066)$ & $0.759(0.559-1.030)$ & $0.706(0.447-1.115)$ & $0.769(0.420-1.406)$ \\
\hline SA & 1.099 (0.890-1.358) & $0.973(0.756-1.253)$ & $0.894(0.645-1.240)$ & $0.950(0.602-1.501)$ & $0.956(0.531-1.722)$ \\
\hline Pre-Eclampsia & 1.017 (0.819-1.263) & 1.069 (0.824-1.388) & $1.153(0.823-1.616)$ & $1.396(0.866-2.252)$ & $1.665(0.900-3.083)$ \\
\hline Gestational hypertension & $1.002(0.787-1.275)$ & $0.925(0.694-1.234)$ & $0.843(0.582-1.220)$ & $0.834(0.497-1.401)$ & $0.874(0.451-1.693)$ \\
\hline Cold Effect (PET) & Lag 0 & Lag 0-2 & Lag 0-6 & Lag 0-13 & Lag 0-20 \\
\hline Stillbirth & $0.931(0.670-1.292)$ & 0.787 (0.546-1.134) & $0.642(0.407-1.013)$ & $0.633(0.329-1.217)$ & $0.669(0.290-1.544)$ \\
\hline LBW & $0.704(0.385-1.289)$ & $0.757(0.394-1.456)$ & $0.607(0.276-1.333)$ & $0.356(0.103-1.224)$ & $0.301(0.067-1.356)$ \\
\hline PTL & $0.992(0.823-1.196)$ & $1.001(0.818-1.224)$ & 1.139 (0.877-1.479) & $1.419(0.947-2.126)$ & $1.521(0.894-2.589)$ \\
\hline SA & $0.991(0.811-1.211)$ & 0.999 (0.800-1.247) & $0.987(0.745-1.308)$ & $1.045(0.695-1.571)$ & $1.162(0.687-1.964)$ \\
\hline Pre-Eclampsia & 1.077 (0.874-1.327) & $1.038(0.828-1.301)$ & $1.105(0.833-1.465)$ & $1.138(0.746-1.736)$ & $0.890(0.508-1.559)$ \\
\hline Gestational hypertension & $0.974(0.782-1.213)$ & $0.906(0.710-1.157)$ & $0.855(0.626-1.167)$ & $0.903(0.571-1.428)$ & $0.954(0.523-1.739)$ \\
\hline
\end{tabular}

${ }^{a}$ The cumulative effects of hot thermal stress on adverse pregnancy outcomes, with 99th percentile of PET (45.4 ${ }^{\circ} \mathrm{C}$ ) relative to 75 th percentile of PET ( $39.1^{\circ} \mathrm{C}$ )

${ }^{b}$ The cumulative effects of cold thermal stress on adverse pregnancy outcomes, with 1 st percentile of PET (6.4 $\left.{ }^{\circ} \mathrm{C}\right)$ relative to 25 th percentile of PET $\left(16.9^{\circ} \mathrm{C}\right.$ )

compared to mothers exposed in only the last week. These results suggested that exposure to hot thermal stress should be considered not only in the last week of pregnancy, but also in longer periods. Strand et al. also found that increased temperatures increased the probability of stillbirth before 36 weeks' gestation, and the risk of stillbirth associated with high temperatures was greater in early gestation [39]. Studies have reported the effects of cold weather as well. Ha et al., (2017) conducted a study on 22,3375 single births in 12 US cities between 2002 and 2008, and reported that chronic exposure to local hot (OR: 3.71, 95\% CI: 3.07-4.47) and cold (OR: 4.75, $95 \%$ CI: 3.95-5.71) weather relative to mild weather, throughout pregnancy was associated with an increased risk of stillbirth. Also, for every $1{ }^{\circ} \mathrm{C}$ increase in temperature in the week before delivery, in hot seasons (May-September), the risk of stillbirth increased by $6 \%$ (95\% CI: $3-9 \%$ ); and it seemed that only warm weather had a significant acute association with the risk of stillbirth, especially in the week before delivery [40]. Bruckner et al. (2014) conducted a retrospective cohort study in Uppsala, Sweden, from 1915 to 1929, and showed that cold weather increased the risk of stillbirth, but contrary to our findings warm weather had a protective effect, and for every $1{ }^{\circ} \mathrm{C}$ increase in temperature throughout pregnancy, the risk of stillbirth decreased by $8 \%[41]$.

The mechanism of effect of temperature on stillbirth is unclear, but it seems that changes in hormonal levels and increase in fetal circulation demand in the mother may increase her susceptibility to heat disorders. High thermal stress may cause water shortages in the mother and be harmful to the fetus. Inadequate fluids in the mother can reduce blood volumes and cause uterine contractions and stillbirth [42]. Low asymptomatic levels of thermal stress in the mother might theoretically result in increased shunting of blood to the periphery, as a heat dissipation mechanism. This can result in altered placental and umbilical blood perfusion and reduced heat exchange with the fetus [43]. Also, extreme temperatures can lead to compromised endothelial function as well as rheological changes, both of which may affect blood pressure and blood viscosity [44, 45]. These responses may ultimately alter maternal-fetal exchange and disturb fetal growth and survival [46].

In relation to LBW, both high values of PET in the 90th, 95th and 99th percentiles and low values of PET in the 5th and 25th percentiles, increased the risk of LBW throughout all lags. Also, hot thermal stress of PET increased the risk of LBW. Similarly, other studies confirm the effect of hot and cold weather on LBW. A retrospective observational study, conducted by Sun et al., (2019), based on data from nearly 30 million births in 403 cities in the US, found that high temperature (> 90th percentile) throughout pregnancy was associated with increased risk of small for gestational age (SGA) [OR: 1.041 (95 \% CI: 1.029-1.054)] and reduced birth weight [ -15 g (95\% CI: $-17 g_{-}-13$ g)]. On the other hand, low temperature $(\leq 10$ th percentile) was not associated with $\mathrm{SGA}[\mathrm{OR}=1.003(95 \% \mathrm{CI}: 0.991,1.015)]$ risk, but a slight decrease in birth weight [-6 g $(95 \%$ CI: $-8 \mathrm{~g}$ $-4 \mathrm{~g})$ ] was observed [47].

Grace et al., (2015), conducted a study in 19 African countries, on nearly 70,000 births, over 20 years, and noticed that with increased warm days and reduced rainfall at any point in pregnancy, a significant increase in LBW was observed in sub-Saharan Africa [13]. Also, Kloog et al., (2015) conducted a study in Massachusetts, and 


\section{$\underline{\text { Hot Effect (PET) }}$}

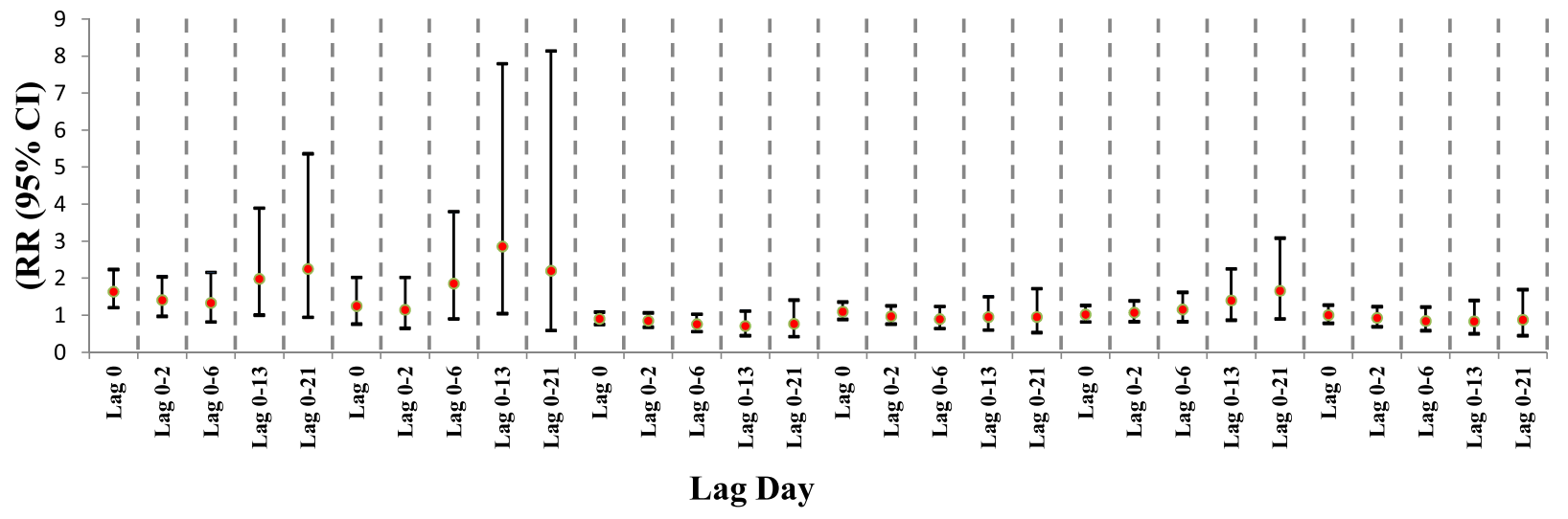

\section{Cold Effect (PET)}

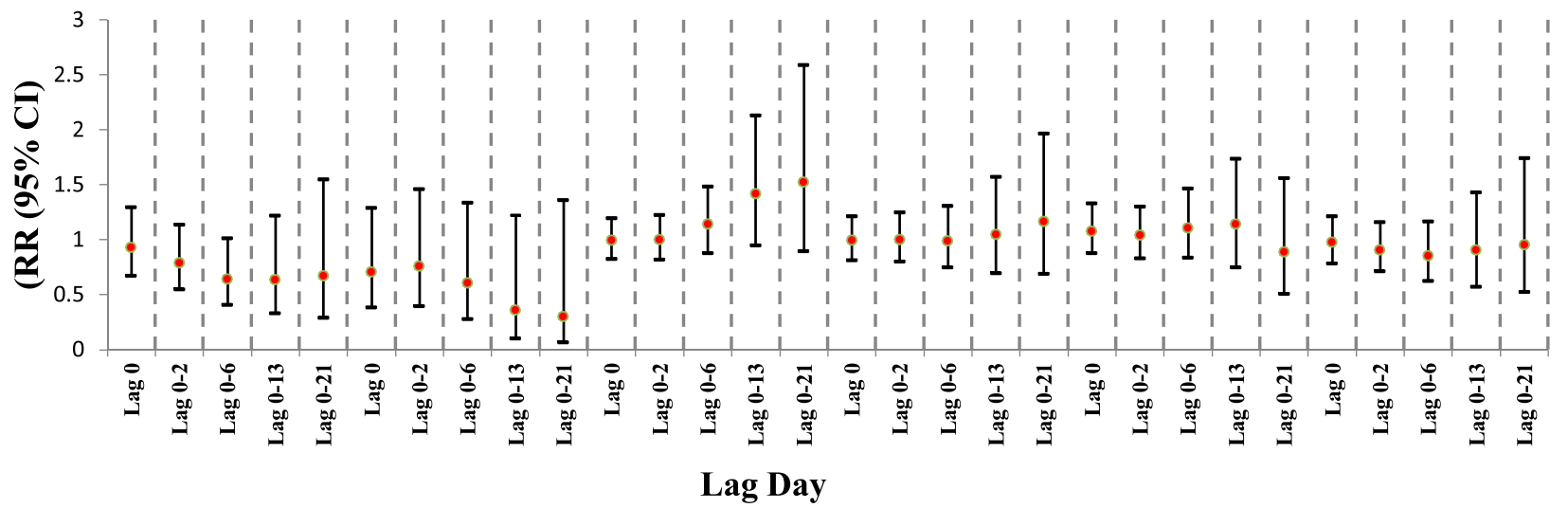

Fig. 1 The relative risks ( $95 \% \mathrm{Cls}$ ) of hot and cold thermal stress of PET on adverse pregnancy outcomes at different lag days. *Statistically significant.

found that temperature had an inverse relation with birth weight, and for each IQR increase in temperature $\left(8.4{ }^{\circ} \mathrm{C}\right)$ during the last 3 months of pregnancy, mean birth weight decreased by $16.7 \mathrm{~g}$ [48].

On the other hand, Hartig and Catalano (2013) stated that the risk of very low birth weight $(<1500 \mathrm{~g})$ was related to ambient cold temperatures, during the cold summers of Sweden [49]. Contrary to our results, Bruckner et al., (2014), in a study in Uppsala, Sweden found no relation between ambient temperature and birth weight [41]. Researchers think high and low thermal stress are associated with oxidative stress and systemic inflammation [50, 51]; and high thermal stress leads to the release of the heat shock proteins (HSPs) including HSP-70 in humans [52]. Increased HSP-70 levels are effective in causing intrauterine growth restriction (IUGR) and may lead to a range of adverse pregnancy outcomes $[53,54]$. In addition, higher or lower than average temperatures are also directly associated with changes in blood viscosity and uterine blood flow $[55,56]$ which can affect the growth of the fetus.

Concerning preterm labor, the results of our study did not show any significant relation between the effect of PET and PTL. Similarly, two cohort studies suggested that there was no increase or decrease in the risk of preterm birth among those who were exposed to short-term cold temperatures throughout their pregnancy $[57,58]$.

However, some studies have stated that both hot and cold weather, affect PTL. For example, in Sabzevar, Iran, an increased risk of preterm birth at both very hot and very cold temperatures especially at 0 till 8 lag days was observed [59]. Also, Li et al., (2018), reported that high and low temperature in the second and third trimesters of pregnancy increased the risk of stillbirth and preterm labor, respectively, in Brisbane, during 1993-2013. The results also showed that the effects of low temperature, were 
stronger, and the effects of high temperature, were weaker for both preterm delivery and stillbirth over time [60].

In relation to gestational hypertension, the results of this study showed that low levels of PET in the 1st, 5th and 25th percentiles reduce the risk of hypertension. In contrast, the study done by Melo et al., (2014), on 26, 125 admitted pregnant women, between 2000 and 2006 in Recife, Brazil, reported that during the cold months, the incidence of hypertension disorders in pregnancy significantly increased, and the lowest mean monthly incidence was in February (9.95\%) and the highest in August $(21.54 \%)$ [19]. Some longitudinal studies have examined seasonal variations in blood pressure during pregnancy, and found that blood pressure in winter and summer months are at their highest and lowest, respectively [17, 18]. But Wellington and Mulla (2012), in Texas, observed a low prevalence of hypertension in pregnant women in winter compared to autumn [61]. Based on the studies mentioned above and the results of a systematic study by TePoel et al. (2011), hypertension in pregnancy occurs mostly in winter [62]. There are various possible mechanisms involved in the effect of cold weather on hypertension, including increased risk of seasonal infections [63], physiological responses to cold, decreased physical activity $[64,65]$, and the reduction of vitamin D levels in plasma $[17,66]$. Sunlight is the main source of vitamin D [67]. Researchers think the reduction of this vitamin is associated with an increased risk of hypertension [68]. Since Ahvaz has hot summers and cool winters, people prefer to do more physical activity and are more exposed to outside air and sunlight in the winter. Therefore, possibly due to more physical activity and normal levels of vitamin D, cold weather has a protective effect on hypertension in pregnancy in this city.

In this study, no significant relation was found between temperature changes and preeclampsia. Similar to this a 36-month research on 11,958 newborns in Mississippi, found no association between the incidence of hypertension in pregnancy and seasonal variation [69]. However, a study from the northeast of Iran found a significant association between monthly temperature changes and preeclampsia prevalence; and the highest prevalence of preeclampsia was seen in summer, especially in September (11.1\%) and August (10.3\%) and the lowest prevalence was seen in winter and early spring, especially in January (5.6\%) and April (5.7\%) [70]. Tam et al., conducted a study in Hong Kong, between 1995 and 2002, and found that women who were pregnant in the summer and had been exposed to higher temperatures were more likely to have preeclampsia [14]. On the other hand, an analysis about the monthly changes of preeclampsia by Shental et al., in Negev, Israel showed that the lowest and highest incidence of preeclampsia occurred in the hottest and coldest months, respectively [71]. However, these findings are inconsistent and more studies with more accurate exposure methods are required.

Although, the relation between temperature and some adverse pregnancy outcomes has been studied before in Iran, the present study included abortion and gestational hypertension for the first time. This study comprehensively examined the effect of PET index on six adverse pregnancy outcomes.

This study had some limitations, including the lack of some health and individual data such as maternal weight, body mass index, and physical activity. Also, this was an ecological study, which means that these results are at population level and cannot be generalized to the individual level. Air pollution parameters had been measured at population level and we were not aware of the individual exposure status.

\section{Conclusions}

The results of this study showed that hot and cold thermal stress may be associated with increased risk of stillbirth, and LBW. Increasing our understanding about the link between temperature changes and adverse pregnancy outcomes in societies sensitive to climate change is essential for improving maternal and fetal health. Pregnant women should be aware of the risk of high and low temperatures for unborn babies and should be encouraged to protect themselves from excessive thermal stress.

\section{Abbreviations \\ PET: Physiological equivalent temperature; LBW: Low birth weight; \\ PTL: Preterm labor; SA: Spontaneous abortion; DLNM: Lag non-linear models; $\mathrm{NO}_{2}$ : Nitrogen dioxide; $\mathrm{SO}_{2}$ : Sulfur dioxide; $\mathrm{PM}_{10}$ : Particles with a diameter of less than 10 micrometers; EM: Expectation maximization; AIC: Akaike \\ information criteria; SGA: Small for gestational age; IUGR: Intrauterine growth restriction; WBGT: Wet-bulb globe temperature; MEMI: Munich energy \\ balance for individuals}

\section{Acknowledgements \\ The authors wish to express their gratitude to Ms. Yalda Sabbaghan for her kind assistance.}

\section{Authors' contributions}

$\mathrm{MD}$ conceived and designed the project. MD acquired the data. MD and NKho analyzed and interpreted the data. NKho and NKha wrote the paper. All authors approved the final text.

\section{Funding}

This study was funded and supported by Ahvaz Jundishapur University of Medical Sciences, Grant No: U-98107.

Availability of data and materials

Data are available from the corresponding author upon reasonable request..

\section{Declarations}

Ethics approval and consent to participate

Ethics Approval for the present study was acquired from the Ethics Committee of Ahvaz Jundishapur University of Medical Sciences (Code: IR.AJUMS.REC.1398.435). According to the national guidelines studies such as 
this, do not require individual consent. All administrative permissions and/or licenses were acquired by our team to access the data used in our research.

\section{Consent for publication}

Not applicable.

\section{Competing interests}

The authors declare that they have no competing interests.

\section{Author details}

'Department of Epidemiology and Biostatistics, Menopause Andropause Research Center, Ahvaz Jundishapur University of Medical Sciences, Ahvaz, Iran. ${ }^{2}$ Environmental Health Engineering Research Center, Kerman University of Medical Sciences, Kerman, Iran.

\section{Received: 20 August 2020 Accepted: 13 May 2021 Published online: 04 June 2021}

\section{References}

1. Burton I, Ebi KL, McGregor G. Biometeorology for adaptation to climate variability and change. In: Biometeorology for Adaptation to Climate Variability and Change. edn.: Springer; 2009. pp. 1-5.

2. Oleson K, Monaghan A, Wilhelmi O, Barlage M, Brunsell N, Feddema J, Hu L, Steinhoff D. Interactions between urbanization, heat stress, and climate change. Clim Change. 2015;129(3-4):525-41.

3. Lee W. Historical global analysis of occurrences and human casualty of extreme temperature events (ETEs). Nat Hazards. 2014;70(2):1453-505.

4. Aboubakri O, Khanjani N, Jahani Y, Bakhtiari B. Attributable risk of mortality associated with heat and heat waves: A time-series study in Kerman, Iran during 2005-2017. J Therm Biol. 2019:82:76-82.

5. Nakai S, Itoh T, Morimoto T. Deaths from heat-stroke in Japan: 1968-1994. Int J Biometeorol. 1999;43(3):124-7.

6. Wang J, Tong S, Williams G, Pan X. Exposure to Heat Wave During Pregnancy and Adverse Birth Outcomes: An Exploration of Susceptible Windows. Epidemiology. 2019;30:115-21.

7. Rammah A, Whitworth KW, Han I, Chan W, Hess JW, Symanski E. Temperature, placental abruption and stillbirth. Environment international. 2019;131:105067

8. Ha S, Zhu Y, Liu D, Sherman S, Mendola P. Ambient temperature and air quality in relation to small for gestational age and term low birthweight. Environmental research. 2017:155:394-400.

9. Auger N, Fraser WD, Smargiassi A, Bilodeau-Bertrand M, Kosatsky T. Elevated outdoor temperatures and risk of stillbirth. Int J Epidemiol. 2017;46(1):200-8

10. Basu R, Sarovar $\vee$, Malig BJ. Association between high ambient temperature and risk of stillbirth in California. Am J Epidemiol. 2016;183(10):894-901.

11. Carolan-Olah M, Frankowska D. High environmental temperature and preterm birth: a review of the evidence. Midwifery. 2014;30(1):50-9.

12. Booth GL, Luo J, Park AL, Feig DS, Moineddin R, Ray JG. Influence of environmental temperature on risk of gestational diabetes. Cmaj. 2017; 189(19):E682-9.

13. Grace K, Davenport F, Hanson H, Funk C, Shukla S. Linking climate change and health outcomes: Examining the relationship between temperature precipitation and birth weight in Africa. Glob Environ Change. 2015:35:125-37.

14. Tam WH, Sahota DS, Lau TK, Li CY, Fung TY. Seasonal variation in preeclamptic rate and its association with the ambient temperature and humidity in early pregnancy. Gynecol Obstet Invest. 2008;66(1):22-6.

15. Tran TC, Boumendil A, Bussieres L, Lebreton E, Ropers J, Rozenberg P, Aegerter P: Are meteorological conditions within the first trimester of pregnancy associated with the risk of severe pre-eclampsia? Paediatric and perinatal epidemiology 2015, 29(4):261-270.

16. Lin Y, Hu W, Xu J, Luo Z, Ye X, Yan C, Liu Z, Tong S. Association between temperature and maternal stress during pregnancy. Environ Res. 2017;158: 421-30.

17. Bodnar LM, Daftary A, Markovic N, Schatzman CL, Roberts JM. Seasonal variation in gestational blood pressure. Hypertens Pregnancy. 2006;25(3) 271-83.

18. Metoki H, Ohkubo T, Watanabe $Y$, Nishimura M, Sato $Y$, Kawaguchi M, Hara A, Hirose T, Obara T, Asayama K. Seasonal trends of blood pressure during pregnancy in Japan: the babies and their parents' longitudinal observation in Suzuki Memorial Hospital in Intrauterine Period study. J Hypertens. 2008; 26(12):2406-13.
19. Melo B, Amorim M, Katz L, Coutinho I, Figueiroa JN. Hypertension, pregnancy and weather: is seasonality involved? Rev Assoc Méd Bras. 2014; 60(2):105-10.

20. Abdel-Ghany A, Al-Helal I, Shady M: Human thermal comfort and heat stress in an outdoor urban arid environment: a case study. Advances in Meteorology 2013, 2013.

21. Brake $R$, Bates $G$. A valid method for comparing rational and empirical heat stress indices. Ann Occup Hyg. 2002;46(2):165-74.

22. Epstein Y, Moran DS. Thermal comfort and the heat stress indices. Industrial health. 2006:44(3):388-98.

23. Esmaili R, Montazeri M. The determine of the Mashad bioclimatic condition base on hourly data. Geography and Environmental Planning 2013, 24(1).

24. Blazejczyk K, Epstein Y, Jendritzky G, Staiger H, Tinz B. Comparison of UTCl to selected thermal indices. Int J Biometeorol. 2012;56(3):515-35.

25. Matzarakis A, Mayer $\mathrm{H}$, Iziomon MG. Applications of a universal thermal index: physiological equivalent temperature. Int J Biometeorol. 1999;43(2): 76-84.

26. Iran SCo: Data on the 2016 census. Tehran: Statistical Centre of Iran. Available at: https://www.amar.org.ir. 2016.

27. Worldatlas: Hottest Cities in the World. Worldatlas.com. https://www. worldatlas.com/articles/the-hottest-cities-in-the-world.html. Accessed December 17, 2019. 2019.

28. Afshari Safavi A, Kazemzadeh Gharechobogh H, Rezaei M. Comparison Of EM algorithm and standard imputation methods for missing data: a questionnaire study on diabetic patients. Iran J Epidemiol. 2015;11(3):43-51.

29. Roshan G, Yousefi R, Kovács A, Matzarakis A. A comprehensive analysis of physiologically equivalent temperature changes of Iranian selected stations for the last half century. Theor Appl Climatol. 2018;131(1-2):19-41.

30. Lee $\mathrm{H}$, Mayer $\mathrm{H}$. Validation of the mean radiant temperature simulated by the RayMan software in urban environments. Int J Biometeorol. 2016;60(11): 1775-85.

31. Sharafkhani R, Khanjani N, Bakhtiari B, Jahani Y, Tabrizi JS. Physiological equivalent temperature index and mortality in Tabriz (the northwest of Iran). J Therm Biol. 2018;71:195-201.

32. Yi W, Chan AP. Effects of temperature on mortality in Hong Kong: a time series analysis. Int J Biometeorol. 2015;59(7):927-36.

33. Luo Y, Zhang Y, Liu T, Rutherford S, Xu Y, Xu X, Wu W, Xiao J, Zeng W, Chu C. Lagged effect of diurnal temperature range on mortality in a subtropical megacity of China. PloS one. 2013;8(2):e55280.

34. Gasparrini A, Armstrong B, Kenward MG. Distributed lag non-linear models. Statistics in medicine. 2010;29(21):2224-34.

35. Sharafkhani R, Khanjani N, Bakhtiari B, Jahani Y, Tabrizi JS, Tabrizi FM. Diurnal temperature range and mortality in Tabriz (the northwest of Iran). Urban Climate. 2019;27:204-11.

36. Guo Y, Barnett AG, Yu W, Pan X, Ye X, Huang C, Tong S. A large change in temperature between neighbouring days increases the risk of mortality. PloS one. 2011:6(2):e16511.

37. Rylander C, Øyvind Odland J, Manning Sandanger T. Climate change and the potential effects on maternal and pregnancy outcomes: an assessment of the most vulnerable-the mother, fetus, and newborn child. Glob Health Action. 2013;6(1):19538.

38. Asamoah B, Kjellstrom T, Östergren P-O: Is ambient heat exposure levels associated with miscarriage or stillbirths in hot regions? A cross-sectional study using survey data from the Ghana Maternal Health Survey 2007. International journal of biometeorology 2018, 62(3):319-330.

39. Strand LB, Barnett AG, Tong S. Maternal exposure to ambient temperature and the risks of preterm birth and stillbirth in Brisbane, Australia. Am J Epidemiol. 2011;175(2):99-107.

40. Ha S, Liu D, Zhu Y, Soo Kim S, Sherman S, Grantz KL, Mendola P. Ambient temperature and stillbirth: a multi-center retrospective cohort study. Environ Health Perspect. 2017;125(6):067011

41. Bruckner TA, Modin B, Vågerö D. Cold ambient temperature in utero and birth outcomes in Uppsala, Sweden, 1915-1929. Ann Epidemiol. 2014;24(2): $116-21$

42. Stan CM, Boulvain M, Pfister R, Hirsbrunner-Almagbaly P. Hydration for treatment of preterm labour. Cochrane Database of Systematic Reviews 2013(11).

43. Ziskin MC, Morrissey J. Thermal thresholds for teratogenicity, reproduction, and development. Int J Hyperth. 2011;27(4):374-87.

44. García-Trabanino R, Jarquín E, Wesseling C, Johnson RJ González-Quiroz M, Weiss I, Glaser J, Vindell JJ, Stockfelt L, Roncal C. Heat stress, dehydration, and 
kidney function in sugarcane cutters in El Salvador-a cross-shift study of workers at risk of Mesoamerican nephropathy. Environ Res. 2015;142:746-55.

45. Zhang X, Zhang S, Wang C, Wang B, Guo P. Effects of moderate strength cold air exposure on blood pressure and biochemical indicators among cardiovascular and cerebrovascular patients. Int J Environ Res Public Health. 2014;11(3):2472-87.

46. Slama R, Darrow L, Parker J, Woodruff TJ, Strickland M, Nieuwenhuijsen M, Glinianaia S, Hoggatt KJ, Kannan S, Hurley F. Meeting report: atmospheric pollution and human reproduction. Environ Health Perspect. 2008;116(6): $791-8$.

47. Sun S, Spangler KR, Weinberger KR, Yanosky JD, Braun JM, Wellenius GA. Ambient temperature and markers of fetal growth: a retrospective observational study of 29 million US singleton births. Environ Health Perspect. 2019;127(6):067005.

48. Kloog I, Melly SJ, Coull BA, Nordio F, Schwartz JD. Using satellite-based spatiotemporal resolved air temperature exposure to study the association between ambient air temperature and birth outcomes in Massachusetts. Environ Health Perspect. 2015;123(10):1053-8.

49. Hartig T, Catalano R. Cold summer weather, constrained restoration, and very low birth weight in Sweden. Health Place. 2013;22:68-74.

50. Ferguson KK, Kamai EM, Cantonwine DE, Mukherjee B, Meeker JD, McElrath TF. Associations between repeated ultrasound measures of fetal growth and biomarkers of maternal oxidative stress and inflammation in pregnancy. Am J Reprod Immunol. 2018;80(4):e13017.

51. Kahle JJ, Neas LM, Devlin RB, Case MW, Schmitt MT, Madden MC, DiazSanchez D. Interaction effects of temperature and ozone on lung function and markers of systemic inflammation, coagulation, and fibrinolysis: a crossover study of healthy young volunteers. Environ Health Perspect. 2014; 123(4):310-6.

52. Daugaard $M$, Rohde $M$, Jäättelä $M$. The heat shock protein 70 family: Highly homologous proteins with overlapping and distinct functions. FEBS Lett. 2007:581(19):3702-10.

53. Fukushima A, Kawahara H, Isurugi C, Syoji T, Oyama R, Sugiyama T, Horiuchi $\mathrm{S}$. Changes in serum levels of heat shock protein 70 in preterm delivery and pre-eclampsia. Journal of Obstetrics Gynaecology Research. 2005;31(1):72-7.

54. Hnat MD, Meadows JW, Brockman DE, Pitzer B, Lyall F, Myatt L. Heat shock protein-70 and 4-hydroxy-2-nonenal adducts in human placental villous tissue of normotensive, preeclamptic and intrauterine growth restricted pregnancies. Am J Obstet Gynecol. 2005;193(3):836-40.

55. Keatinge WR, Coleshaw SR, Easton JC, Cotter F, Mattock MB, Chelliah R. Increased platelet and red cell counts, blood viscosity, and plasma cholesterol levels during heat stress, and mortality from coronary and cerebral thrombosis. Am J Med. 1986;81(5):795-800.

56. Bouchama A, Knochel JP. Heat stroke. N Engl J Med. 2002;346(25):1978-88.

57. Schifano P, Lallo A, Asta F, De Sario M, Davoli M, Michelozzi P. Effect of ambient temperature and air pollutants on the risk of preterm birth, Rome 2001-2010. Environment international 2013, 61:77-87.

58. Vicedo-Cabrera AM, Olsson D, Forsberg B. Exposure to seasonal temperatures during the last month of gestation and the risk of preterm birth in Stockholm. Int J Environ Res Public Health. 2015;12(4):3962-78.

59. Mohammadi D, Naghshineh E, Sarsangi A, Sakhvidi MJZ. Environmental extreme temperature and daily preterm birth in Sabzevar, Iran: a time-series analysis. Environ Health Prev Med. 2019;24(1):5.

60. Li S, Chen G, Jaakkola JJ, Williams G, Guo Y. Temporal change in the impacts of ambient temperature on preterm birth and stillbirth: Brisbane, 1994-2013. Science of the Total Environment 2018, 634:579-585.

61. Wellington K, Mulla ZD. Seasonal trend in the occurrence of preeclampsia and eclampsia in Texas. Am J Hypertens. 2012;25(1):115-9.

62. TePoel MR, Saftlas AF, Wallis AB. Association of seasonality with hypertension in pregnancy: a systematic review. J Reprod Immunol. 2011; 89(2):140-52.

63. Arechavaleta-Velasco F, Koi H, Strauss JF III, Parry S. Viral infection of the trophoblast: time to take a serious look at its role in abnormal implantation and placentation? J Reprod Immunol. 2002:55(1-2):113-21.

64. Sorensen TK, Williams MA, Lee I-M, Dashow EE, Thompson ML, Luthy DA. Recreational physical activity during pregnancy and risk of preeclampsia. Hypertension. 2003;41(6):1273-80.

65. Saftlas AF, Logsden-Sackett N, Wang W, Woolson R, Bracken MB. Work, leisure-time physical activity, and risk of preeclampsia and gestational hypertension. Am J Epidemiol. 2004;160(8):758-65.
66. Baker AM, Haeri S, Camargo CA Jr, Espinola JA, Stuebe AM. A nested casecontrol study of midgestation vitamin D deficiency and risk of severe preeclampsia. J Clin Endocrinol Metab. 2010;95(11):5105-9.

67. Zittermann A, Schleithoff SS, Koerfer R. Putting cardiovascular disease and vitamin D insufficiency into perspective. Br J Nutri. 2005;94(4):483-92.

68. Forman JP, Giovannucci E, Holmes MD, Bischoff-Ferrari HA, Tworoger SS, Willett WC, Curhan GC. Plasma 25-hydroxyvitamin D levels and risk of incident hypertension. Hypertension. 2007:49(5):1063-9.

69. Elongi J-P, Tandu B, Spitz B, Verdonck F: Influence de la variation saisonnière sur la prévalence de la pré-éclampsie à Kinshasa. Gynécologie obstétrique \& fertilité 2011, 39(3):132-135.

70. Nasiri R, Ahmadi Shadmehri A, Khajeh Ghiassi P, Sarafraz Yazdi M, Mazloum Farsi Baf M. Association of meteorological factors and seasonality with preeclampsia: a 5-year study in northeast of Iran. Clin Exp Hypertens. 2014; 36(8):586-9.

71. Shental O, Friger M, Sheiner E. Ethnic differences in the monthly variation of preeclampsia among Bedouin and Jewish parturients in the Negev. Hypertens Pregnancy. 2010;29(3):342-9.

\section{Publisher's Note}

Springer Nature remains neutral with regard to jurisdictional claims in published maps and institutional affiliations.
Ready to submit your research? Choose BMC and benefit from:

- fast, convenient online submission

- thorough peer review by experienced researchers in your field

- rapid publication on acceptance

- support for research data, including large and complex data types

- gold Open Access which fosters wider collaboration and increased citations

- maximum visibility for your research: over $100 \mathrm{M}$ website views per year

At BMC, research is always in progress.

Learn more biomedcentral.com/submissions 